\title{
Synthesis of a Nonpeptide Carbon-11 Labeled Substance P Antagonist for PET Studies
}

\author{
RENATO B. DEL ROSARIO', THOMAS J. MANGNER', DAVID L. \\ GILDERSLEEVE ${ }^{l}$, PAUL D. SHREVE ${ }^{1}$, DONALD M. WIELAND ${ }^{1 *}$, \\ JOHN A. LOWE III $^{2}$, SUSAN E. DROZDA ${ }^{2}$ and R. MICHAEL SNIDER ${ }^{2}$
}

\begin{abstract}
'Division of Nuclear Medicine, University of Michigan Medical Center, Ann Arbor, MI 48109-0028 and ${ }^{2}$ Central Research Division, Pfizer Inc., Groton, CT 06340, U.S.A.
\end{abstract}

(Received 15 September 1992)

\begin{abstract}
CP 96,345 is a nonpeptide high affinity antagonist of the substance $\mathrm{P}\left(\mathrm{NK}_{1}\right)$ receptor. The radiosynthesis of [ $\left.{ }^{11} \mathrm{C}\right] \mathrm{CP} 96,345$ suitable for Positron Emission Tomography (PET) applications is described. [ $\left.{ }^{11} \mathrm{C}\right] \mathrm{CP}$ 96,345 was prepared by O-methylation of a desmethyl precursor via in situ generation of its phenolate salt. The in vivo tissue distribution of [ $\left.{ }^{11} \mathrm{C}\right] \mathrm{CP} 96,345$ in guinea pigs $(n=2)$ at 5 and $30 \mathrm{~min}$ was determined. Uptake was low in brain $(\approx 0.04 \%$ dose/g) and highest $(\approx 1-2 \%$ dose $/ \mathrm{g})$ in the spleen and lungs. The present findings indicate that the use of $\left.{ }^{11} \mathrm{C}\right] \mathrm{CP} 96,345$ in PET might be more applicable to the study of substance $\mathrm{P}$ receptors in peripheral tissues involved with inflammatory disease and arthritis.
\end{abstract}

\section{Introduction}

The compound CP 96,345 has recently been reported to be the first potent nonpeptide antagonist of substance P (Lowe et al., 1991, 1992; McLean et al., 1991; Snider et al., 1991). CP 96,345 binds stereoselectively and with high affinity $\left(K_{\mathrm{d}}=0.2 \mathrm{nM}\right)$ to the substance $\mathbf{P}(\mathrm{NK}-1)$ receptor (Lowe et al., 1992; Snider et al., 1991). Radiolabeled CP 96,345 has the potential for in vitro and in vivo localization of substance $P$ receptor sites. Successful mapping of substance $P$ receptor sites may yield useful diagnostic information in the study of arthritis, inflammatory diseases and carcinoid tumor (Payan, 1989). A preliminary account of the characterization of substance $\mathrm{P}$ receptor sites in guinea pig brain using $\left[{ }^{3} \mathrm{H}\right] \mathrm{CP}$ 96,345 (Lowe et al., 1991) has been published (McLean, 1991). The present work describes the synthesis of carbon-11 analogue CP 96,345 suitable for Positron Emission Tomography applications and its in vivo tissue distribution in guinea pigs.

\section{Experimental}

\section{Radiosynthesis}

$\left[{ }^{11} \mathrm{C}\right] \mathrm{CP} 96,345,3$ (Fig. 1), was prepared by reaction of (2S,3S)-cis -2-(diphenylmethyl)- $N$-[(2-hydroxy-

*Author for correspondence phenyl)methyl]-1-azabicyclo[2.2.2]-octan-3-amine, 2, with $\left[{ }^{11} \mathrm{C}\right]$ methyl iodide. The desmethyl precursor 2 was prepared from the previously reported optically active compound 1 (Lowe et al., 1992) by imine formation with salicylaldehyde (Fig. 1) followed by reduction with borane/methyl sulfide. Compound 2 (1-2 mg) was dissolved in $8-9 \mu \mathrm{L}$ of $1 \mathrm{M}$ tetrabutylammonium hydroxide in methanol (Aldrich Chemical $\mathrm{Co}$.) in a septum-capped vial. The methanolic solution was evaporated under a gentle stream of nitrogen for $1-2 \mathrm{~h}$ and the residue of phenolate salt was dissolved in $150-200 \mu \mathrm{L}$ of dimethyl formamide. The $\left[{ }^{11} \mathrm{C}\right]$ methyl iodide was trapped in the solution at $-40^{\circ} \mathrm{C}$ and the reaction mixture was subsequently heated at $85-90^{\circ} \mathrm{C}$ for $5 \mathrm{~min}$. $\left[{ }^{11} \mathrm{C}\right] \mathrm{CP} 96,345$ was purified by reverse phase HPLC using a Waters Bondapak CN column $(3.9 \times 300 \mathrm{~mm})$ eluted with ethanol/0.1 $\mathrm{M}$ ammonium acetate $(1: 4)$. $\left[{ }^{11} \mathrm{C}\right] \mathrm{CP}$ 96,345 eluted at $19-20 \mathrm{~min}$ at a flow rate of $2.3 \mathrm{~mL} / \mathrm{min}$. Radiochemical yields of $30-50 \%$ (decay corrected) were obtained in a total synthesis time of $45-60 \mathrm{~min}$ to $1 \mathrm{~h}$ from end-of-beam. Analytical HPLC of the HPLC purified 3 showed a high radiochemical purity $(<95 \%)$ and a specific activity $>1000 \mathrm{Ci} / \mathrm{mmol}$ (end-of-synthesis). An authentic sample of CP 96,345 provided by Pfizer, was used as a reference standard. Radiochromatographic analysis was performed with a $4.6 \times 250 \mathrm{~mm}$ Phenomenex Ultremex C18 IP using acetonitrile/0.1 M ammonium acetate $(95: 5,3.0 \mathrm{~mL} / \mathrm{min})$ as solvent. 



\section{Animal studies}

["C]CP 96,345 was formulated for animal injection by a nine-fold dilution of the HPLC purified product with physiologic saline. Guinea pigs were anesthesized with ether, administered $50-100 \mu \mathrm{Ci}$ via femoral vein injection of the above formulation and sacrificed at 5 and $30 \mathrm{~min}$. Biodistribution data for two guinea pigs per each time point in the brain and peripheral tissues are given in Tables 1 and 2 .

\section{Results and Discussion}

The chiral phenolic precursor 2 was prepared from the intermediate quinuclidine amine 1 (Lowe et al., 1992) (Fig. 1) via imine formation and borane/methyl sulfide reduction. The radiosynthesis of $\left[{ }^{11} \mathrm{C}\right] \mathrm{CP}$ 96,345 was readily accomplished by O-methylation of 2 via in situ generation of its phenolate salt using excess tetrabutylammonium hydroxide in dimethyl formamide. Co-injection of HPLC of the radiolabeled product along with authentic CP 96,345 gave a single radioactive peak (retention time $=19-22 \mathrm{~min}$ ) coincident with the UV peak of $\left[{ }^{11} \mathrm{C}\right] \mathrm{CP} 96,345$. The highly lipophilic nature of $\left[{ }^{11} \mathrm{C}\right] \mathrm{CP} 96,345$ resulted in very long HPLC elution times using C-8 or C-18 columns which presented practical problems in product recovery and reformulation for animal studies. The use of a Bondapak $\mathrm{CN}$ column made it possible to elute the product in a buffer-ethanol $(4: 1)$ solvent system which could be conveniently diluted for subsequent injection into guinea pigs.

In vivo biodistribution of $\left[{ }^{11} \mathrm{C}\right] \mathrm{CP} 96,345$ was performed in the guinea pig. This choice of animals model allowed a direct comparison between $\left[{ }^{3} \mathrm{H}\right] \mathrm{CP}$ 96,345 and $\left[{ }^{11} \mathrm{C}\right] \mathrm{CP} 96,345$ since in vitro results with the tritiated compounds have been published (McLean et al., 1991). Furthermore, the regional binding of substance $P$ to substance $P(N K-1)$ receptors have been studied in the guinea pig brain (Dam



Table 2. Uptake of $\left[{ }^{11} \mathrm{C}\right] \mathrm{CP} 96,345$ in

\begin{tabular}{lcc}
\multicolumn{3}{c}{ peripheral tissues } \\
\hline & \multicolumn{2}{c}{$\%$ Dose $/ \mathrm{g}$} \\
\cline { 2 - 3 } Tissue & $5 \mathrm{~min}$ & $30 \mathrm{~min}$ \\
\hline Left ventricle & 0.45 & 0.19 \\
Left atrium & 0.35 & 0.18 \\
Lung & 1.78 & 2.06 \\
Liver & 0.71 & 0.47 \\
Spleen & 1.51 & 0.71 \\
Pancreas & 0.35 & 0.27 \\
Blood & 0.048 & 0.084 \\
\hline
\end{tabular}


and Quirion, 1986). Biodistribution data for $\left[{ }^{11} \mathrm{C}\right] \mathrm{CP}$ 96,345 in various brain tissues and peripheral tissues 5 and 30 min post-injection ( $n=2$ guinea pigs) are summarized in Tables 1 and 2. Table 1 shows that the overall brain uptake of $\left[{ }^{11} \mathrm{C}\right] \mathrm{CP} 96,345$ was minimal, $\approx 0.1 \%$ of the injected dose at $30 \mathrm{~min}$. The distribution of activity was nearly uniform $(\approx 0.04 \%$ dose/g) and nonselective in various regions of the brain, including the striatum, cerebellum, cortex, hypothalmus, hippocampus and olfactory bulb. The calculated variances for brain regions (Table 1) were very small with a maximum value of 0.000 ? for the olfactory bulb. Brain activity levels were slightly lower than blood activity and $\approx 3$ times lower than heart activity. Table 2 shows that highest peripheral accumulation of activity occurred in the spleen and lungs. For tissues in Table 1, the calculated variances were higher, ranging from 0.00006 to 0.670 .

Regional selective binding of both $\left[{ }^{3} \mathrm{H}\right]$ substance $\mathrm{P}$ (Dam and Quirion, 1986) and $\left[{ }^{3} \mathrm{H}\right] \mathrm{CP} 96,345$ (Lowe et al., 1991) to substance $P$ receptors sites in the brain have been determined qualitatively. For example, qualitative autoradiographic studies of both $\left[{ }^{3} \mathrm{H}\right] \mathrm{CP}$ 96,345 and $\left[{ }^{3} \mathrm{H}\right]$ substance $P$ have indicated modest binding in the striatum, hippocampus and hypothalmus and dense binding in the olfactory bulb. By contrast, Table 1 shows that the in vivo localization of $\left[{ }^{11} \mathrm{C}\right] \mathrm{CP} 96,345$ was nearly identical in the striatum, cerebellum, cortex, hypothalmus, hippocampus and olfactory bulb. Since the calculated variances in Table 1 were very small, additional in vivo studies with larger groups of animals were not conducted.

Based on the present preliminary evaluation of $\left[{ }^{11} \mathrm{C}\right] \mathrm{CP} 96,345$, we conclude that $\mathrm{CP} 96,345$ is unsuitable as an in vivo marker of substance $P$ receptors in the brain. HPLC data and $\log \mathrm{P}$ measurements $(\log \mathrm{P}=4.5)$ indicate that the free base form of $\mathrm{CP}$ 96,345 , with its two highly basic nitrogens, may exist mostly in cationic form, either a monocation or possibly even a dication, thus precluding its passage through the blood-brain barrier. Alternative experiments for the low brain uptake, such as extensive binding to blood proteins, cannot be ruled out. PET studies with [ $\left.{ }^{11} \mathrm{C}\right] \mathrm{CP} 96,345$ might be more appropriately applied to the detection of substance $P$ receptors in tissue regions of interest involved with inflammatory disease and arthritis (Payan, 1989). Studies to determine the specific binding of $\left[{ }^{11} \mathrm{C}\right] \mathrm{CP} 96,345$ to various peripheral tissues and its applications in animal models of such diseases are underway.

Acknowledgements - We especially thank Philip Sherman and Teresa Pisani for performing the biodistribution experiments. This work was supported by the National Institutes of Health Grant Nos HL27555 and NS25656.

\section{References}

Dam T. V. and Quirion R. (1986) Pharmacological characterization and autoradiographic localization of substance $P$ receptors in guinea pig brain. Peptides 7, 855 .

Lowe J. A., Drozda S. E., Snider R. M. et al. (1991) Preparation and radiolabeling of CP-96,345, the first non-peptide substance $\mathrm{P}$ antagonist. Bioorg. Med. Chem. Lett. 1, 129

Lowe J. A., Drozda S. E., Snider R. M., Longo K. P., Zorn S. H., Morrone J., Jackson E. R., McLean S., Bryce D. K., Bordner J., Nagahisa A., Kanai Y., Suga O. and Tsuchiya M. (1992) The discovery of $(2 S, 3 S)$-cis-2(diphenylmethyl)- $N$-[(2-methoxyphenyl)methyl]-1-azabicyclo[2.2.2]octan-3-amine as a novel, nonpeptide substance P antagonist. J. Med. Chem. 35, 2591.

McLean S., Ganong A. H., Seeger T. F. et al. (1991) Activity and distribution of binding sites in brain of a nonpeptide substance $\mathbf{P}\left(\mathbf{N K}_{1}\right)$ receptor antagonist. Science $251,437$.

Payan D. G. (1989) Neuropeptides and inflammation: the role of substance P. Ann. Rev. Med. 40, 341.

Snider R. M., Constantine J. W., Lowe J. A. et al. (1991) A potent nonpeptide antagonist of the substance $\mathbf{P}$ receptor. Science 251, 435. 